\title{
Antagonism of Microbial Consortium Decomposers in Deadly Water-borne Pathogens in Domestic Wastewater
}

\author{
Lud Waluyo \\ University of Muhammadiyah Malang \\ ludwaluyo63@gmail.com
}

\begin{abstract}
The higher the domestic waste pollutes the body of water, the more likely it is to cause various infectious diseases to spread easily. Domestic waste must be controlled and processed first with ecofriendly methods and techniques to avoid a negative impact on public health and environment. The potential microbe which decomposes the waste and kills the pathogens is produced in the laboratory. An antagonistic test of pathogens to explore the potential of microbial strains found biological pesticides in lethal pathogenic microbes which exist in domestic wastewater. The bacteria test consists of pathogens, namely Salmonella typhi, Shigella dysenteriae, Vibrio cholerae, and Escherichia coli. The consortium consists of 4 strains of bacteria namely Bacillus cereus strain BQAR-01d $16 \quad S \quad$ rRNA (A), Bacillus thuringiensis strain MSS-2 16 S rRNA (B), Bacillus cereus strain JDA-1 $16 \mathrm{~S}$ rRNA (C), and Bacillus sp. B31 (2008) $16 \mathrm{~S} r R N A$ (D). The consortium formula consists of $\mathrm{ABC}, \mathrm{ABD}, \mathrm{BCD}$, and $\mathrm{ABCD}$ consortium strain. The result shows that the consortium formula of heterotrophic bacteria strain with the highest antagonistic power against pathogens in vitro is the ABC consortium formula. This formula can be used as a consortium of waste decomposers to reduce negative impacts on public health and the environment.
\end{abstract}

Keywords: antagonistic, microbe decomposer, waterborne pathogen, domestic wastewater.

\section{INTRODUCTION}

The higher the domestic (household) waste pollutes the body of water, the more likely it is to cause various infectious diseases. Domestic waste is a source of microbial contaminants that causes various diseases, and it potentially plays a role as a source of disease transmission by pathogens carried by water. Consequently, the domestic waste must be controlled and processed first with eco-friendly methods and techniques to avoid a negative impact on public health and environment [6], [11], [26], [34], [37].

Liquid waste is wastewater which derives from human activities such as settlements, trades, offices and industries. It can be found in ground water, surface water, and rain water that may exist [11], [20], [21], [26], [36]. Domestic wastewater is liquid waste which derives from household activities, residentials, restaurants, offices, commercials, apartments, and dormitories; including wastewater from the toilet, bathroom, sink, and cooking area. Domestic wastewater is also produced from the remnants of washing water, bathroom wastes, housing washings, cooking oil, detergents, soaps, and other waste materials [2], [4], [6], [11], [15], [26], [40].

Liquid waste generally consists of $99.9 \%$ water. The amount of solid material suspended in it is so small that it is reflected in units of ppm (part per million). The determination of degrees of soil wastewater is strongly influenced by visible physical properties; important physical properties of solid matter, clarity, odor, and color [1], [2], [5], [7], [32], [33]. Other components in domestic wastewater are detergent, laundry soap, bath soap, shampoo, and residual disinfectant [14], [27], [32], [38].

\section{METHOD}

The research design is experimental conducted by the laboratory of method approach. The laboratory methods were performed to examine the potential characteristics of heterotrophic detergent-tolerant strains of bacteria as ingredients of a consortium formula of domestic wastewater disposal inoculum. The antagonistic test of type and number of strains of heterotrophic bacteria is against pathogenic bacteria with Completely Randomized Design 1 Factor. This experiment used 3 replications. Antagonistic potential test was against pathogens to explore potential isolates found as biological pesticides (bio pesticides) in lethal microbial pathogens which exist in domestic wastewater.

The study sample was taken from heterotrophic bacteria isolated and compared with 0.5 Farland Mac solutions with the density of $1.5 \times 10^{8}$ cells / ml. The sampling was done randomly. The independent variable in this study was the type of microbial strain. The dependent variables in this study were antagonistic forces of detergent with tolerant strains of bacteria against pathogens (Salmonella typhi, Shigella dysenteriae, Vibrio cholerae, and E. coli). Antagonistic power was derived by measuring the pathogenic zone of pathogenic bacteria using the sliding term with mm units.

The study design looked for the best formula on the consortium formula of microbial inoculum waste decomposition by testing a consortium of 4 heterotrophic bacteria species with a ratio of 1: 1: 1: 1; $\mathrm{ABC}$ : 
consortium of species $\mathrm{ABC}, \mathrm{ABD}$ : consortium of species $\mathrm{ABD}, \mathrm{BCD}$ : consortium of species $\mathrm{BCD}, \mathrm{ABCD}$ : consortium of species ABCD. The research material of this stage is isolated detergent heterotrophic bacteria strains from domestic wastewater, pathogenic bacteria. The research tool consists of incubator, ent cast, colony counter, autoclave, water bath, petri dish, ose, reaction tube, magnetic stirrer, oven, cooler box, microscope, glass object, glass cover, spirit light, culture tube, The medium used was Nutrient Agar, Nutrient Broth, and the selected medium, Bussnell Hass.

This procedure is used to determine the ability of inhibition of heterotrophic strains of detergent-tolerant bacteria against pathogenic microbes. The method used is the paper disk method [16], [25], [29]. Some of the pathogenic bacteria in waste ie Salmonella typhi, Shigella dysenteriae, Vibrio cholerae, and E. coli were grown on Nutrient Agar with a population density of $10^{6}$ cells/ ml of $100 \mu \mathrm{l}$ [22]. Subsequently, in the medium, it was placed a sterile paper disk dipped in $100 \mu \mathrm{l}$ pre-prepared. From each of the heterotrophic bacterial isolates, it was found the same density of aseptic pathogenic bacteria. The inoculated medium was then incubated at $37^{\circ} \mathrm{C}$ for 48 hours. The next step is to observe the inhibition zone formed. The stock of bacterial isolate suspension used Nutrient Agar medium with the composition of $3 \mathrm{gr}$ of meat extract, 5 gr pepton, aquadest $1,000 \mathrm{cc}$, and agar 1.5 - 2.0\% [3], [9], [12], [24], [28], [30].

The antagonistic power of microbial type and isolate number to inhibit zone of heterotrophic bacteria Salmonella typhi, Shigella dysenteriae, Vibrio cholerae, and $E$. coli were analyzed by Anava test which was preceded by normality test and homogeneity of 5\% significance level. The next test is to know the different mean of treatment in one variable that was continued by Duncan test at 5\% significance level.

\section{RESULT}

Table 1. Inhibitory zone diameter data of the consortium formula of heterotrophic bacteria tolerant to detergent against various pathogens $(\mathrm{cm})$.

\begin{tabular}{lllll}
\hline \multirow{2}{*}{ Consortium } & \multicolumn{5}{l}{ Average diameter of pathogen inhibition zone $(\mathrm{cm})$} \\
\cline { 2 - 5 } & $\begin{array}{l}\text { Salmonella } \\
\text { typhi }\end{array}$ & $\begin{array}{l}\text { Shigella } \\
\text { dysenteriae }\end{array}$ & $\begin{array}{l}\text { Vibrio } \\
\text { cholerae }\end{array}$ & Escherichia coli \\
\hline $\mathrm{ABC}$ & $2.44 \pm 0.07 \mathrm{c}$ & $2.64 \pm 0.21 \mathrm{~b}$ & $2.98 \pm 0.25 \mathrm{~b}$ & $2.84 \pm 0.30 \mathrm{~b}$ \\
\hline $\mathrm{ABD}$ & $1.39 \pm 0.06 \mathrm{~b}$ & $1.40 \pm 0.21 \mathrm{a}$ & $1.18 \pm 0.28 \mathrm{a}$ & $1.40 \pm 0.29 \mathrm{a}$ \\
\hline $\mathrm{BCD}$ & $2.03 \pm 0.11 \mathrm{a}$ & $1.19 \pm 0.23 \mathrm{a}$ & $1.31 \pm 0.24 \mathrm{a}$ & $1.39 \pm 0.32 \mathrm{a}$ \\
\hline $\mathrm{ABCD}$ & $1.29 \pm 0.13 \mathrm{a}$ & $1.13 \pm 0.25 \mathrm{a}$ & $1.18 \pm 0.23 \mathrm{a}$ & $1.24 \pm 0.32 \mathrm{a}$ \\
\hline
\end{tabular}

Description: The letters that accompany the numbers in the table show the notation of the Duncan test. Values followed by the same letter show no significant difference at significance level of $5 \%$.

The data on antagonistic capability of consortium of heterotrophic bacteria species on pathogens were analyzed by Analysis of One Path Variant which was preceded by Normality test and Homogeneity test, then continued by Duncan test if $\mathrm{F}$ arithmetic $\geq \mathrm{F}$ table at $5 \%$ significance level. Further tests will explain the differences in antagonistic ability of the highest pathogen of 4 consortium of heterotrophic bacterial species.

The test results of Normality with One-Sample Kolmogorov-Smirnov Test showed significance to Salmonella typhi 0.097; significance to Shigella dysenteriae 0.126; significance to Vibrio cholerae 0.051 , and significance to Escherichia coli 0.183. The four dependent variables are $>0.05$ which means the data of all normal parameters. Homogeneity Test of Variance with Levene's Test, significance of obstacles zone diameter of Salmonella typhi 0.099; significance of obstacles zone diameter against Shigella dysenteriae 0.940; significance of obstacles zone diameter of Vibrio cholerae 0.926; and significance of obstacles zone diameter of Escherichia coli 0.856 . The four dependent variables have significance $>0.05$, so it can be said the data variance of the four homogeneous indicators. Thus, the Anava test can be continued.

The results of the calculation of Varian Analysis indicate F arithmetic Salmonella typhi (259.47), F arithmetic Shigella dysenteriae (73.07), F arithmetic Vibrio cholerae (82.74), and Escherichia coli $\mathrm{F}$ (43.45) $\geq$ $\mathrm{F}$ p value table $=0.000$ thus $\mathrm{Ho}$ is rejected and the research hypothesis is accepted, ie there is significant difference in antagonistic potential ability (antibiotics) consortium of heterotrophic-tolerant detergent-tolerant bacterial species against pathogens (Salmonella typhi, Shigella dysenteriae, Vibrio cholerae, and Escherichia coli).

The next step is to choose from each pathogen indicator, a consortium of heterotrophic bacterial strain that has the greatest antagonistic power against all four pathogens, an antagonistic potential by looking at the mean diameter of the largest zone of inhibition. Further, Duncan test results in each dependent variable.

The greatest antagonistic capability of the heterotrophic bacterial consortium on pathogens (Salmonella typhi) is a consortium of ABC bacteria. The ABC Consortium differs significantly from the BCD consortium, ABD consortium, and ABCD consortium in antagonistic ability against Salmonella typhi at a significance level of $5 \%$. The BCD consortium differs significantly from the ABD consortium and ABCD consortium in antagonistic ability against Salmonella typhi at a significance level of 5\%. The ABC consortium has the greatest antagonistic ability against Salmonella typhi bacteria.

The greatest antagonistic potential of the heterotrophic bacterial consortium against Shigella dysenteriae is the $\mathrm{ABC}$ consortium. The $\mathrm{ABC}$ consortium capability differs significantly at the $5 \%$ significance level with 3 other heterotrophic bacterial consortiums; the $\mathrm{ABD}$, the $\mathrm{BCD}$, and the $\mathrm{ABCD}$ consortium. The ABD consortium does not differ significantly and statistically from the $\mathrm{ABD}$ and the ABCD consortium. The consortium of heterotrophic ABC species has the greatest antagonistic ability against Shigella dysenteriae.

The greatest antagonistic capability of the heterotrophic bacterial consortium against Vibrio 
cholerae is the $\mathrm{ABC}$ consortium. The $\mathrm{ABC}$ consortium capability was statistically significant at significance level of $5 \%$ with the $\mathrm{BCD}, \mathrm{ABCD}$, and $\mathrm{ABD}$ consortium. The $\mathrm{ABC}$ consortium is the best consortium of its antagonistic abilities against the Vibrio cholerae bacteria.

The greatest antagonistic capability of a heterotrophic bacterial consortium against Escherichia coli pathogens is the $\mathrm{ABC}$ consortium. The antagonistic abilities of the $\mathrm{ABC}$ consortium differ significantly and statistically at the 5\% significance level from the ABD consortium, the $\mathrm{BCD}$ consortium, and the ABCD consortium. The ABC consortium of heterotrophic bacteria is the best antagonistic to Escherichia coli bacteria. In general, the $\mathrm{ABC}$ consortium has the highest antagonistic power against many pathogens.

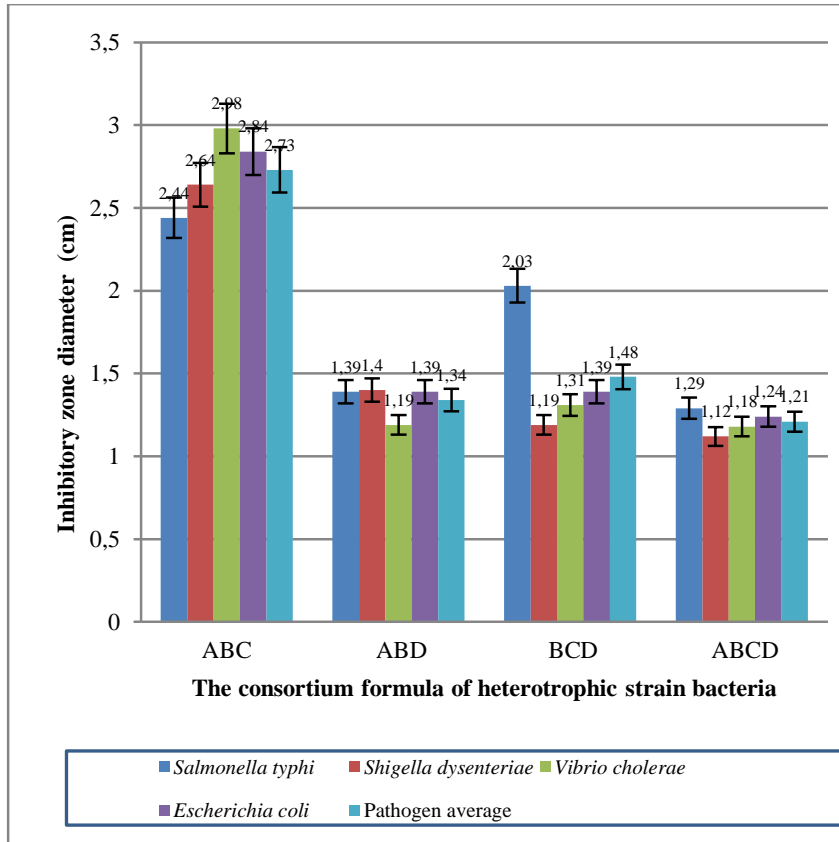

Figure 1. Inhibition zone diameter of the consortium formula of heterotrophic bacteria strain tolerant to detergent against various pathogens $(\mathrm{cm})$.

An antagonistic test of a heterotrophic bacterial consortium against pathogens showed the result that there were significant differences in 4 heterotrophic bacterial consortiums (ABC consortium, ABD consortium, BCD consortium, and $\mathrm{ABCD}$ consortium) against various pathogens. The bacterial consortium that has the highest antagonistic power to Salmonella typhi is the $\mathrm{ABC}$ consortium consisting of Bacillus cereus strain BQAR-01d $16 S$ rRNA (A), Bacillus thuringiensis strain MSS-2 16 S rRNA (B), Bacillus cereus strain JDA-1 $16 \mathrm{~S}$ rRNA (C) compared to the BCD consortium (Bacillus thuringiensis strain MSS-2 $16 S$ rRNA (B), Bacillus cereus strain JDA-1 $16 S$ rRNA (C)) and Bacillus sp. B31 (2008) $16 S$ rRNA (D). Likewise, ABC's antagonistic abilities against Shigellla dysenteriae, Vibrio cholerae, and Escherichia coli were the highest compared to the $\mathrm{ABD}, \mathrm{BCD}$, and $\mathrm{ABCD}$ consortium. Theoretically, the secondary metabolites of the $\mathrm{ABC}$ consortium have the highest damage to the cell wall of Salmonella typhi bacteria, such as the subtilisin enzyme released by Bacillus substilis, and cereolisin by Bacillus cereus [8], [10], [13], [17], [18], [23], [26], [31], [37], [39], [40]. In general, the ability of a consortium of heterotrophic ABC species is best antagonistic to pathogens.

\section{CONCLUSION}

The consortium formula of heterotrophic bacterial inoculum bacteria decomposers which is the most effective in degrading organic compounds and antagonistic power against pathogens in vitro is the $\mathrm{ABC}$ consortium formula.

\section{REFERENCES}

[1] Adesemoye, A.O., Opere B.O., and Makinde S.C.O. Microbial content of abattoir wastewater and its contaminated soil in Lagos, Nigeria. Academic Journal. 82, 766-799. 2006.

[2] Alexander, M. Biodegradation dan bioremediation, pp 79-89. Academic Press, San Diego, California, USA. 1994.

[3] American Public Health Association. Standard Methods for the Examination of Water and Wastewater, $21^{\text {st }}$ ed., pp 9-54. Washington, D.C., USA. 2005.

[4] Amund, O.O., Ilori, M.O., and Odetundun, F.R. Degradation of commercial detergent products by microbial populations of the Lagos lagoon. Folia Microbiologica. 42, 353-356. 1997.

[5] Atlas, R. and Bartha, R. Microbial Ecology, Fundamentals and Application, $3^{\text {rd }}$ ed., pp 25-35. The Benyamin/Cummings Publishing Company Inc., New York, USA. 1993.

[6] Atlas, R.M., and Philp, J. Bioremediation: Applied Microbial Solutions for Realworld Environmental, pp 101-120, ASM Press, Michigan, USA. 2005.

[7] Beck, Bernd. Biodegradation and Persintence: Handbook of Environmental Chemistry, Vol. 2, pp 201-215, Park K, Springer-Verleg Berlin Heildelberg. 2001.

[8] Benathen, I.A. and Saccardi, M. Killer Pigments in Bacteria. An Ecological Nigthmare. The American Biology Teacher. 62, 9-15. 2000.

[9] Bhatia, C. Handbook of Environmental Microbiology, Vol. 3., pp 45-59, Atlantic, Co., New Delhi, India. 2008.

[10] Boon, N., Goris, J., de Vos, P., Verstraete, and Top, E. M. Bioaugmentation of Activated Sludge by Indigenous 3-Chloroaniline-Degrading Comamonas testosteroni 21 Strain, 12gfp, J. Appl and Environ Microbiol. 66, 2906-2913. 2000.

[11] Boyd, R.F. Basic Medical Microbiology, Fifth ed., pp 273-275, Little Brow and Company, BostonNew York- Toronto-London. 1995.

[12] Bridson, E.Y. The Oxoid Manual. 8 th Edition, Oxoid Limited, Wade Road, Basingstoke, Hampshire, England. 1998. 
[13] Cirne, D.G., Bjornsson, L., Alves, M., and Mattiasson, B. Effects of bioaugmentation by an anaerobic lipolytic bacterium on anaerobic digestion of lipid-rich waste, J. of Chem Technol and Biotechnology. 81, 1745-1752. 2006.

[14] Cullum, D.C. Introduction to Surfactant Analysis, pp. 93-97. Blackie Academic \& Professional, Glasgow, England. 1994.

[15] Dinas Kominfo Pemkot Kota Malang. Kondisi Kota Malang (The Condition of Malang), pp. 78-90. Pemkot Malang, Malang, Indonesia. 2011.

[16] Eniola, K.I.T., and Olayemi, A.B. Linear alkylbenzene sulfonate tolerance in bacteria isolated from sediment of tropical water bodies polluted with detergents, int. J. Trop.Biol. 56, 1595-1601. 2008.

[17] Feachem, R.G., Bradley, D.J., Garelick, H.and Mara, D.D. Sanitation and Disease: Health Aspects of Excreta and Sullage Management, pp. 83-94, John Wiley and Sons, Chichester-New York-Brisbane-Toronto-Singapore. 1983.

[18] Fogarty, W. M. Microbial Enzymes and Biotechnology, pp. 25-39, Applied Science Publisher, London and New York, England and USA. 1983.

[20] Gerardi, M.H. Wastewater Bacteria, pp. 61-78, John Wiley \& Sons, Wiley Interscience, USA. 2006.

[21] Heritage, J., Glyn, E., Evans, V., dan Killington, R.A. Introductory Microbiology, pp. 56-54, Science, Inc., USA. 1996.

[22] Holt, J.G., Krieg, N.R., Sneath, P.H.A, Staley, J,T., and William, S.T. Bergey's Manual of Determinative Bacteriology, pp. 559-562, The William \& Wilkins Co., Philadelphia, USA. 1994.

[23] Kim, J.R., Jerzy, D., Bruns, MA., and Logan, B.E. Removal of Odors from Swine Wastewater by Using Microbial Fuel Cells, J. Appl and Environ Microbiol. 74, 2540-2543. 2008.

[24] Kim, H.S., Oh, K.K, Lee, C.W., Kim, J.W., Park, G.W., Jeon, Y.J., and Lee, J.H. Microorganisms and preparation for disposing of organic wastewater'.World Intellectual Property Organization (WO/1999/036506). 1999.

[25] Madigan, M.T., Martinko, J.M., Parker, J. Brock Biology of Microorganism, pp. 614-642, PrenticeHall International, Inc., New York, USA. 2003.

[26] Metcalf and Eddy. Wastewater Engineering, Treatment Disposal, Re Use, Series Water Resources and Environmental Engineering, pp. 261-279, McGraw-Hill Book 21Co., New York, USA. 2003.

[27] Ojo, O.A., and Oso, B.A. Isolation and characterization of synthetic detergent-degraders from wastewater, African Journal of Biotechnology. 7, 3753-3760. 2008.
[28] Quang, L.K. EM Technology Application in Vietnam and Some Results in Environment Treatment', Research, testing, and Application of EM Technology in Agriculture and Enviromental Sanitation. 1998

[29] Radojevics, M. and Vladimir, B. N. Practical Environmental Analysis, pp. 78-82, The Royal Society of Chemistry, Cambridge, England. 1999.

[30] Scragg, Alan. Environmental Biotechnology, pp. 89-94, Addison Wesley Longman, Ltd. Singapore. 1999.

[31] Sigh, A. and Ward, O.P. Biodegradation and Bioremediation, pp. 93-97, Springer. 2004.

[32] Wind, T., Henkel KgaA. The Role of detergents in the phosphate-Balance of European Surface Waters'. J.E-Water. 20, 1-5. 2007.

[33] Ghazemi, A. Rostami, M., and Yaddaninia. In Vitro antagonistic and biodegradation activity of a newly isolated Delftia tsuruhatensis from rice plant in Iran. International Journal of Agriculture and Crop Science, 4-2, 40-44. 2012.

[34] Tsvetanova, Z., Najdenski, H. Pathogenic Bacteria in Waters and Drinking Water Associated Biofilms. Ecological Engineering and Enviroment Protection, No.1, p 50-61. 2017.

[35] Boulter, J.I., Trevors, J.T., and Boland G.J. Microbial Studies of Compost: bacterial identifications, and their potential for turfgrass pathogen suppressions. World Journal Microbiology \& Biotechnology 18: 661-671. 2002.

[36] Baudisova, D. Microbial pollution of water from agriculture. Plant Soil Environ. 55(10): 429-435. 2009.

[37] Felchtmayer, J., Deng, L., and Griebler, C. Antagonistic Microbial Interaction: Contributions and Potential Applications for Controlling Pathogen in the Aquatic Systems. Frontiers in Microbiology. 8. 2192. 2017.

[38] Jung, A.V., Cann, P.L., Roig, B, Thomas, M.F. Microbial Contamination Detection in Water Resources: Interest of CurrentOPtical Methods, Trends and Need in Context of Climate Change. International Research and Public Health. 11, 4292-4310. 2014.

[39] Tzeng, Y,M., Rao, Y.K., Tsay, K.J, and Wu, W.S. Effect of cultivation condition on spore production from Bacillus amyloliquefaciens B. 128 and its antagonism to Botrys elliptica. Journal Applied Mikrobiology. 104. 1275-1282. 2008.

[40] Naliskha, I., Muskhazli, M., and Faruzan, T. Production of Bioactive Compounds by Bacillus subtilis against Sclerotium rolfsii. Malaysian Journal of Microbiology, 2, 19-23. 2006. 